\title{
PSYCHOLOGICAL FUNCTIONING OF ADOLESCENTS FROM VIOLENT FAMILIES
}

\author{
Ljiljana Simonović Grujic ${ }^{1}$
}

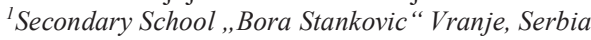

\section{PSIHOLOŠKO FUNKCIONISANJE ADOLESCENATA IZ PORODICA SA NASILJIEM \\ Ljiljana Simonović Grujić ${ }^{1}$ \\ ${ }^{1}$ Gimnazija ,,Bora Stanković“ Vranje, Srbija}

\begin{abstract}
Objective. The aim of the study was to determine the association of family violence with the functioning of the family system, psychological functioning and development of specific characteristics of the adolescents who grew up in a violent families. Methods. The study was carried out on a sample of 308 adolescents, aged 15-18, divided in a FV group of adolescents coming from dysfunctional families $(n=68)$ adolescents who grew up inviolent families and were exposed to family violence, which was reported and processed, and a control group $(n=240)$ adolescents from families in which according to the CPRS-R Questionnaire there was not found any form of violence, alcoholism or any other psychosocial pathology. FACES III Scale and Questionnaire for the examination of psychosocial characteristics of the adolescents and family (Revised CPRS-R) were used for measuring dimensions of family functioning, Cybernetic model of personality dimensions (CON-6) for conative functioning of the adolescents, Test for reasoning images (TRI) for measuring intellectual development and the Scale of Latent Maturity (SLM) for determining the level of psychological maturity. The data were processed by using linear regression analysis. Results. Family functioning disorders caused by family violence were significantly and highly associated with psychological functioning of the adolescents: concern about family relationships $(\beta=-.968)$, need for professional help ( $\beta=-.873)$, cooperation with people $(\beta=.523)$, orientation towards the future $(\beta=.669)$, latent maturity $(\beta=.618)$, psychosomatic reactions $(\beta=-.509)$, dissociative reactions $(\beta=-.591)$, excused absence from school $(\beta=.618)$, unexcused absence from school $(\beta=-.824)$, memory disorders $(\beta=-.541)$, night fears $(\beta=-$ 722), running away from home $(\beta=-.569)$, breaking rules and getting punished at school ( $\beta=-.569)$, conflicts with peers $(\beta=-$ .460). Conative functioning of the adolescents exposed to a violent family environment showed a pathological form of functioning in dissociative, anxiety reactions and social adaptability. Conclusion. Exposure of adolescents to a violent family environment was associated with changes in psychological functioning, development of specific personality characteristics and risk of developing internalized and externalized symptoms when it came to socialadaptation, anxiety and dissociative reactions. The mediators between family violence and psychological functioning and development of the adolescents was family cohesion and disorders within the marital dyad.

Keywords: family violence, psychological functioning of the
\end{abstract} adolescents, specific psychological features of adolescents.

\section{SAŽETAK}

Uvod/Cilj. Cilj istraživanja je utvrđivanje povezanosti porodičnog nasilja sa psihičkim funkcionisanjem i razvojem specifičnih osobina adolescenata. Metode. Istraživanje je sprovedeno na uzorku od 308 adolescenata, uzrasta od 15-18 godina, podeljenih u PN grupu adolescenata ( $n=68)$, koji su odrastali u porodicama sa porodičnim nasiljem i izloženi nasilju, koje je prijavljeno i procesuirano, $i$ kontrolnu grupu $(n=240)$ adolescenata iz porodica $u$ kojima Upitnikom CPRS-R nije utvrđen bilo koji oblik nasilja ili druga psihosocijalna patologija. Skala Faces III $i$ Upitnik za ispitivanje psihosocijalnih karakteristika mladih $i$ porodice (Revidrani CPRS-R) korišćeni su za merenje dimenzija porodičnog funkcionisanja, Kibernetički model dimenzija ličnosti (KON-6) za konativno funkcionisanje adolescenata, Test rezonovanja likova (TRL) za merenje intelektualnog razvoja i Skala latentne zrelosti (SLZ) za utvrđivanje razvoja psihičke zrelosti. Podaci su obrađeni linearnom regresivnom analizom. Rezultati. Poremećaji porodičnog funkcionisanja izazvani nasiljem značajno $(p \leq 0.01)$ su $i$ visoko povezani sa psihičkim funkcionisanjem adolescenata: brigom za porodične odnose ( $\beta=-.968)$, potrebom za stručnom pomoći $(\beta=-.873)$, saradnjom sa ljudima $(\beta=.523)$, orijentacijom $k a$ budućnosti $(\beta=.669)$, latentnom zrelošću $(\beta=.618)$, psihosomatskim reakcijama $(\beta=-.509)$, disocijativnim reakcijama $(\beta=.-591)$, opravdanim izostajanjem iz škole $(\beta=.618)$, neopravdanim izostajanjem $(\beta=-.824)$, poremećajima pamćenja $(\beta=-.541)$, noćnim strahovima $(\beta=-.722)$, bežanjem od kuće $(\beta=-.569)$, kršenjem pravila i kažnjavanjem u školi $(\beta=-.569)$ i sukobima sa vršnjacima $(\beta=-.460)$. Zaključak. Izloženost adolescenata porodičnom nasilju povezano je sa promenama psihičkog funkcionisanja, razvojem specifičnih osobina ličnosti i rizikom od nastanka internalizovanih i eksternalizovanih simptoma u socijalno-adaptivnim, anksioznim i disocijativnim reakcijama. Medijatori između porodičnog nasilja i psihosocijalnog funkcionisanja i razvoja adolescenata su porodična kohezivnost i poremećaji u bračnoj dijadi.

Ključne reči: porodično nasilje, psihološko funkcionisanje adolescenata, specifične osobine adolescenata.

\section{ABBREVIATIONS: \\ FV - Family violence \\ PN - Porodice sa nasiljem}

sciendo

UDK: 364.63-027.553:616.89-053.6 159.922 .7

Ser J Exp Clin Res 2021; 22 (4): 289-299 DOI: $10.2478 /$ sjecr-2019-0007
Corresponding author:
Ljiljana Simonović Grujić, Sime Pogačarević 52,
17500 Vranje, Serbia, E-mail: 1jiljanasimon@gmail.com 


\section{INTRODUCTION}

\section{Functioning of a violent family system}

The study of De Fife et al. (1) pointed out to the relationship between family violence (FV), family functioning problems and numerous psychosocial developmental difficulties of adolescents. Violent family showed a pronounced dysfunction within the marital dyad, which was reflected on all family subsystems. Role reversals in a violent family were associated with failing to satisfy basic psychological needs for security, love, belonging and respect which hindered individual functioning of one or more family members, that is, subsystem differentiation (2).

Family violence was often the result of pronounced violent parents' mental health problems. The structure of a violent person was predominantly characterized by emotional dysregulation, hostility, impulsiveness, bipolar disorder, antisocial personality disorder, substance use disorder (3). Intimate partner violence was significantly associated with poor mother's mental health (4). Abused women suffered more from a high level of depression, anxiety, phobias, posttraumatic symptoms and low self-esteem; they had suicidal ideas and suffered from attempted suicide, auto destructive actions; alcohol, nicotine and other addiction; sleep and diet disorders; social functioning disorders; behavioral problems and unsafe sexual behavior (5). Poor mental health of the mother was associated with the child's increased aggressive behavior, lowered mother's warmth and more frequent physical and psychological abuse of the child. Negative consequences of increased aggression and deficit of the mother's mental health and warmth significantly affected the adolescent's social and behavioral development (6).

The most pronounced consequences of the violence family system were the changes in family dimensions of cohesion and communication among subsystems (7). Weakening of closeness and communication within the marital dyad brought about the weakening of emotional association between the mother and the children (7). Within violent families, $20-60 \%$ of children were themselves exposed to some form of violence - physical, psychological or sexual (8).

\section{Consequences of adolescent growing up in violent families}

The consequences of growing up within violent families were emotional, cognitive, behavioral and health problems (9).Long-term exposure to negative traumatic stress on the part of adolescents from violent families was associated with the sensation of fear, tremor, hyperactive attention and responses that might bring about cognitive problems: low cognitive and school performance (10), lost or inhibited skills of problem and conflict management (11), accepting violent forms of behavior and attitudes, belief in rigid sex stereotypes and men's privileges (12). During their social development, adolescents exposed to family violence had difficulties in establishing contact with their peers (7). Growing up in violent families was associated with increased risk of PTSD (posttraumatic stress disorders) and alcohol addiction (13). Psycho-socio-pathology of adolescents growing up in violent families was associated the most with the characteristic of the families themselves (14). Close family association and social support were important for internalized symptoms: anxiety, acute state of fear, depression, hypersensitivity, acquired helplessness, posttraumatic stress disorder (PTSD), whereas low cohesion intensified externalized symptoms such as aggression, behavioral disorders (lying, thefts, fights, idleness), antisocial and delinquent behavior, substance use disorder, impulsive behavior, attention deficit disorder (ADD), attention deficit and hyperactivity disorder (ADHD), oppositional defiant disorder (ODD) (15).

\section{Symptoms of adolescent from violent families}

Psychopathological symptoms of a child within a violent dysfunctional family system occurred as a consequence of the inability to reduce anxiety and family structure disorder. Resolution of a high fusion level within the family was a sign of low differentiation, because high tension and inter-dependence level brought about emotional cut-off, most frequently at the onset of the first symptoms. High family and marital anxiety was centered on the child/adolescent. The result was the very dysfunction of the child/adolescent (16).

Adolescents fromviolent families had more pronounced symptoms of posttraumatic stress disorders (17) and showed the development of posttraumatic symptomatology: depression, suicidality, anxiety, substance use disorder, delinquency and somatic difficulties (18). Adolescent exposure to verbal and physical abuse was accompanied by depression, delinquency and suicidal ideas (19). Pronounced externalized adolescent problems predicted a high degree of negative emotional expressiveness, hostile reactions and trans-generational transfer of violence (20).

The theoretical concept of this survey was represented by a system family theory, which, through an eclectic approach of theoretical systems, highlights the functioning of a family system in general and its subsystems in the form of establishing family homeostasis and morphogenesis or the ability to adapt to changes (21).

\section{Aims of survey}

The basic aim of the survey was to determine the association between the functioning of a violent family system and the changes in psychological functioning of adolescents coming from such families.

Specific aims of the survey:

1. To determine the effect of family violence on intellectual functioning of adolescents coming from such families.

2. To determine the effect of family violence on conative functioning of adolescents coming from such families.

3. To determine the effect of family violence on the problems of psychosocial development and behavioral disorders. 
4. To determine the effect of family violence on the leve of pronunciation of psychological maturity dimensions on the part of adolescents coming from such families.

\section{METHODS}

\section{Sample/Participant}

The study was conducted on a sample of 308 adolescents, aged 15-18 $(\mathrm{M}=16.5 \pm 1.5)$. There was no difference between the groups by the age $(\mathrm{t}(198)=-1.09, \mathrm{p}=.125$. The sample consisted of two subsamples: the FV one was made up of adolescents growing up in violence families (FV) and exposed to $\mathrm{FV}$, which was reported to and processed at the Centre for Social Work in Vranje $(\mathrm{n}=68 / 22.8 \%, 52.9 \%$ males and $47.1 \%$ females) and the control one made up of ( $240 / 77.3 \%$ , $42.5 \%$ males and $57.5 \%$ females) adolescents coming from families in which there had not been found any type of violence and social pathology using a Revised CPRS-R Questionnaire (22). FACES III Scale (23) and Questionnaire for the Examination of Psychosocial Characteristics of the Adolescents and Family (Revised CPRS-R)were used for measuring dimensions of family functioning, the Scale of Latent Maturity (SLM) (24) for determining the level of psychological maturity, Test for reasoning images (TRI) (25) for measuring intellectual development, Cybernetic model of personality dimensions (CON-6) (26) for conative functioning of the adolescents.

\section{Procedures}

After being acquainted with the Approval by the Ethics Committee of the Medical Faculty in Kragujevac as regards conducting the design of study and upon getting the respective Consent by the Centre for Social Work in Vranje and Secondary School Gimnazija „Bora Stanković” in Vranje, the respondents gave, after being acquainted with the aims of the study, written information consent for participating in the study.

The testing of adolescents coming from functional families was conducted by a school psychologist in the school premises. The testingof adolescents coming from violent families was conducted by psychologists and specialist teachers, who did therapeutic work with the parents and the adolescent or the adolescent only in the Centre's premises. The study was anonymous. Testing total test material took one hour. KON-6 (Test conative functioning personality) respondents filled out for 30 minutes, while answering the Questionnaire (CPRS-R) and FACES III lasted up to $15 \mathrm{~min}$. The study was conducted during the period from 2010. to 2012.

\section{Instruments}

The results for the control group of adolescents coming from families without family violence was obtained by using the revised Questionnaire for determining psychological and social pathology of family members - Revised Conners Parent Rating Scale (CPRS-R). It contains 20 items (22). In this study, reliability estimates for the scores were $\alpha=.94$.

Family dimensions cohesion and adaptability were measured by using the Scale of Family Adaptability and Cohesion (FACES III), which consisted of 20 items. Obtained results were expressed by using raw scores and categories (cohesion: low - dissociated, mild - separated, developed - coherent and high - intertwined; adaptability: low, moderate - flexible, developed - structured, high - rigid) (23) . In this study, reliability estimates for the scores were $\alpha=.89$.

Conative dimensions, measured by the KON-6 Conative Personality Dimensions, were: reaction activity-introversion/extroversion, psychosomatic reactions, anxiety-defence reactions, aggressive-response attacks, dissociative reactions, integrative reaction-social adaptation. It contains 180 items. Conative personality dimensions were expressed in the following categories: superior, above-the-average, average, below-the-average, and pathological functioning (26). In this study, reliability estimates for the scores were $\alpha=.96$.

Psychosocial development of latent maturity: accomplished level of forming personal, social identity and personality identity (differentiation of personality, inclusion into a social community, defining psychological and ideal I) was surveyed by using the Scale of Latent Maturity. The Scale of Latent Maturity was made up of five subscales, with a total ofmultiple choice questions which the respondents answered by choosing from five given anwers: I completely agree, I mostly agree, I cannot make up my mind, I mostly disagree, I do not agree at all. The subscales of latent maturity were: cooperation with other people, frustration tollerance, trust in people, selflessness and orientationtowards the future. As an answer to the question: What are my plans and desires for the future, the respondent should choose from one of the five given answers. Raw scores at these subscales were turned into categories (low, below the average, average, above the average, pronounced), on the basis of the tables in the manual. The values of these scales were accumulated and Latent maturity was obtained. According to the table, raw scores were defined as maturity categories: pronounced immaturity, predominantly immature behaviour, mature behaviour with occasional regression, predominantly mature behaviour, pronounced mature behaviour (24). The reliability of the Scale of Latent Maturity in this study was $\alpha=.92$.

Overall intellectual ability was measured by using the Test of Reasoning Images (25). The test included 45 tasks with six possible answers. Raw scores were transfered into intelligence quotient (IQ), according to standardised tables, into five categories: below the average, average, somewhat above the average, high and gifted. The reliability of the Scale was $\alpha=.97$. 
The reliability was medium and high value $\alpha$ confirms the validity of applied techniques and number of measured dimensions.

\section{Statistical analysis}

Linear regression analysis was used for evaluating the contribution of independent variables to a certain outcome of psychological functioning of adolescents exposed to family violence.

Determining association between the respective types of family: functonal one and a violent family, and psychological functioning of adolescents coming from above mentionedrespectivefamilies, was performed by using linear regression analysis, where the predictor variable was: type of family with two categories coded as dummy variables: $0=$ functional and $1=$ dysfunctional affected by violence.

The level of pronunciation of family and psychological variables was shown by using statistical description techniques.

The level of statistical significance was less than $1 \%(\mathrm{p}<$ $0.01)$ and $5 \%(\mathrm{p}<0.05)$. Data analysis was performed using the software package SPSS version 11.5.

\section{RESULTS}

The results obtained by using the linear regression analysis showed that family violence was a significant $(p=.000)$ predictor of disorders in the functioning of the family and psychosocial development of adolescents growing up in and exposed to family violence (Table 1, Figure 1).

Family violence was significantly associated with cohesion $(\beta=.605)$, among family subsystems. Functional families obtained an average value for the dimension of cohesion $(M=41.050 \pm 4.314)$, which corresponded to category 4 or highly pronounced closeness among family members, as compared with average values in a violent family environment $(M=29.0881 \pm .616)$ in terms of one category lower (3) which corresponded to achieved cohesion. Family violence was significantly associated with un/employment of the father $(\beta=.618, p=.000)$. In violent families, half of the entire numbers of fathers were unemployed $(50.0 \%$, vs. $1.3 \%$ in functional families). Family violence was significantly associated with fathers' mental health. There was a negative correlation $(\beta=-.489)$ between mental problems of the father and family violence. Within violent families, $25.5 \%$ of fathers had a certain mental disorder, compared to $0.0 \%$ in functional families. Family violence significantly affected father - children relationship. There was a negative correlation $(\beta=-.445)$ in nonviolent father's behavior towards the children. The father's punishing or being violent to the children was more frequent within violent families $(17.6 \%$ vs. $1.3 \%)$, as compared with the father - children relationship within functional families.
Disorders in family functioning caused by family violence were $(\mathrm{p}=.000)$ highly associated with disorders in psychological functioning of adolescents in the form of pronounced being worried for family relationships. Obtained highly pronounced negative correlation $(\beta=-.968)$ and a high level of children being worried about their family relationships ( $100 \%$ vs. $0.4 \%$ ), were associated with the need for psychological and psychiatric help with the aim of restoring disrupted psychological balance $(\beta=-.8739)$. Obtained negative correlation between family violence and internalized adolescent homeostasis growing up in a violent family environment showed that $88.2 \%$ got or is still getting expert help from psychologists and psychiatrics, compared to $1.7 \%$ adolescents from functional families.

Adolescents from violent families were significantly associated with impaired intellectual development $(\beta=.357)$. Adolescents from functional families had a category of overall intelligence somewhat above the average $(M=112.775 \pm$ 7.307), as compared to adolescents from a violent family environment who showed lower or average intelligence levels $\mathrm{M}=104.235 \pm 8.038$ ).

Significant negative correlations were obtained between family violence and cognitive functioning. Adolescents from a violent family environment had bigger cognitive problems: memory disorders $(\beta=-.541 ; 58.8 \%$ vs. $5.4 \%)$, attention deficit disorders $(\beta=-.338 ; 76.5 \%$ vs. $27.9 \%)$, unexcused $(\beta=-.824 ; M=15.00 \pm 7.596)$ and excused leave from school $(\beta=.618 ; M=51.39 \pm 31.218$ vs. $M=16.04 \pm 11.516)$. Difficulties in intellectual development and learning problems were accompanied with lower school achievement $(\beta=-.408$; $\mathrm{M}=3.25 \pm 1.456$ vs. $\mathrm{M}=4.339 \pm .826$ ). Adolescents from violent families had on the average good achievement at school, as opposed to adolescents from functional families who accomplished very good achievement on the average.

Negative correlations were obtained between family violence and conative functioning of the adolescents.

Adolescents from violent families had difficulties in conative functioning and ran the risk of developing psychopathological symptomatology due to increased psychosomatic $(\beta=-.509 ; \mathrm{M}=72.06 \pm 26.058$, category $4-$ below the average functioning vs. $M=47.05 \pm 11.348$, category 1 - superior functioning), dissociative $(\beta=.-591 ; M=70.68 \pm 26.487$, category 4 - below the average functioning, vs. $M=41.92 \pm 9.774$, category 3 - average functioning), anxiety ( $\beta=-.393 ; M=94.44$ \pm 24.036 , category 4 - below the average functioning, vs. $\mathrm{M}=69.91 \pm 18.169$, category 3 - average functioning) and aggressive reactions $(\beta=-.359, \mathrm{M}=99.97 \pm 18.118$, category 4 - below the average functioning vs. $M=82.81 \pm 12.214$, category 3 - average functioning). Disorders in conative functioning were associated with impaired integrative and adaptive systems of adolescent socialization $(\beta=-.455, \mathrm{M}=77.47$ \pm 23.452 , category 4 - below the average functioning vs. $\mathrm{M}=54.52 \pm 13.257$, category 3 - average functioning). 
Table 1. Linear regression analysis of predictor variable- type of families: 0 - functional family, 1 -violent family

\begin{tabular}{|c|c|c|c|c|c|c|}
\hline Variable & $\mathrm{R}^{\mathrm{a}}$ & $\mathrm{R}^{2 \mathrm{~b}}$ & $\begin{array}{l}\text { Adjusted } \\
\mathrm{R}^{2} \mathbf{c}\end{array}$ & $\overline{B^{d}}$ & $\mathrm{t}-$ test $^{\mathrm{e}}$ & $\mathrm{P}^{\mathrm{f}}$ \\
\hline Latent maturity & .618 & .382 & .379 & .608 & 12.956 & $.000^{* *}$ \\
\hline Cooperation & .523 & .273 & .271 & .523 & 10.116 & $.000^{* *}$ \\
\hline Frustration tolerance & .416 & .173 & .170 & .416 & 7.543 & $.000^{* *}$ \\
\hline Trust & .368 & .135 & .132 & .368 & 6.527 & $.000^{* *}$ \\
\hline Selflessness & .348 & .121 & .118 & .348 & 6.120 & $.000^{* *}$ \\
\hline Orientation towards the future & .669 & .448 & .446 & .669 & 14.864 & $.000^{* *}$ \\
\hline Psychosomatic reactions & .509 & .259 & .257 & -.509 & -9.760 & $.000^{* *}$ \\
\hline Anxiety reactions & .393 & .155 & .152 & -.393 & -7.054 & $.000^{* *}$ \\
\hline Aggressive reactions & .398 & .159 & .156 & -.359 & -7.162 & $.000^{* *}$ \\
\hline Dissocative reactions & .591 & .349 & .346 & -.591 & -12.071 & $.000^{* *}$ \\
\hline Social adaptation & .455 & .207 & .204 & -.455 & -8.422 & $.000^{* *}$ \\
\hline Cohesion & .605 & .366 & .364 & .605 & 12.532 & $.000^{* *}$ \\
\hline Adaptability & .188 & .035 & .032 & .188 & 3.164 & .091 \\
\hline IQ quotient & .357 & .127 & .124 & .357 & 6.298 & $.000^{* *}$ \\
\hline School achievement & .408 & .167 & .164 & .408 & 7.378 & $.000^{* *}$ \\
\hline Excused absence from school & .608 & .389 & .379 & -.618 & -11.360 & $.000^{* *}$ \\
\hline Unexcused absence from school & .824 & .678 & .677 & -.824 & -19.160 & $.000^{* *}$ \\
\hline Employed father & .618 & .381 & .379 & .618 & 12.902 & $.000^{* *}$ \\
\hline Punishing of the mother & .360 & .130 & .126 & -.360 & -6.365 & $.000^{* *}$ \\
\hline Getting punished by the father & .445 & .198 & .195 & -.445 & -8.189 & $.000^{* *}$ \\
\hline Marriage problems & .905 & .918 & .918 & -.958 & -55.313 & $.000^{* *}$ \\
\hline Mental problems of the father & .489 & .240 & .237 & -.489 & -9.222 & $.000^{* *}$ \\
\hline Alcohol abuse & .428 & .180 & .180 & -.428 & -7.806 & $.000^{* *}$ \\
\hline Attention deficit & .338 & .114 & .111 & -.338 & -5.924 & $.000^{* *}$ \\
\hline Memory disorder & .541 & .293 & .290 & -.541 & -10.608 & $.000^{* *}$ \\
\hline Night fears & .722 & .522 & .520 & -.722 & -17.222 & $.000^{* *}$ \\
\hline Enuresis & .323 & .105 & .101 & -.323 & -5.636 & $.000^{* *}$ \\
\hline Phobias & .586 & .343 & .340 & -.586 & -11.914 & $.000^{* *}$ \\
\hline $\begin{array}{l}\text { Being worried about family re- } \\
\text { lationships }\end{array}$ & .968 & .937 & .936 & -.968 & -63.376 & $.000^{* *}$ \\
\hline Conflict with peers & .460 & .212 & .209 & -.460 & -8.554 & $.000^{* *}$ \\
\hline $\begin{array}{l}\text { Getting punished for breaking } \\
\text { rules }\end{array}$ & .592 & .350 & .348 & -.592 & -12.100 & $.000^{* *}$ \\
\hline Running away from home & .569 & .325 & .321 & -.569 & -11.400 & $.000^{* *}$ \\
\hline Professional help & .873 & .762 & .762 & -.873 & -29.527 & $.000^{* *}$ \\
\hline
\end{tabular}

Legend:

${ }^{\mathrm{a}} \mathrm{R}$-regression residual, ${ }^{\mathrm{b}} \mathrm{R}^{2} \mathrm{R}$ square,

${ }^{\mathrm{c}}$ Adjusted $\mathrm{R}{ }^{2},{ }^{\mathrm{d}} \beta$-quotient of correlation, ${ }^{\mathrm{e}} \mathrm{t}$-test, ${ }^{\mathrm{f}} \mathrm{p}$ - significant $\mathrm{p}<0.01$ 
Figure1. Effects of functioning family violence on adolescent psychological functioning: psychological maturity, conative, intellectual functioning, behavioral and psychosocial development disorders

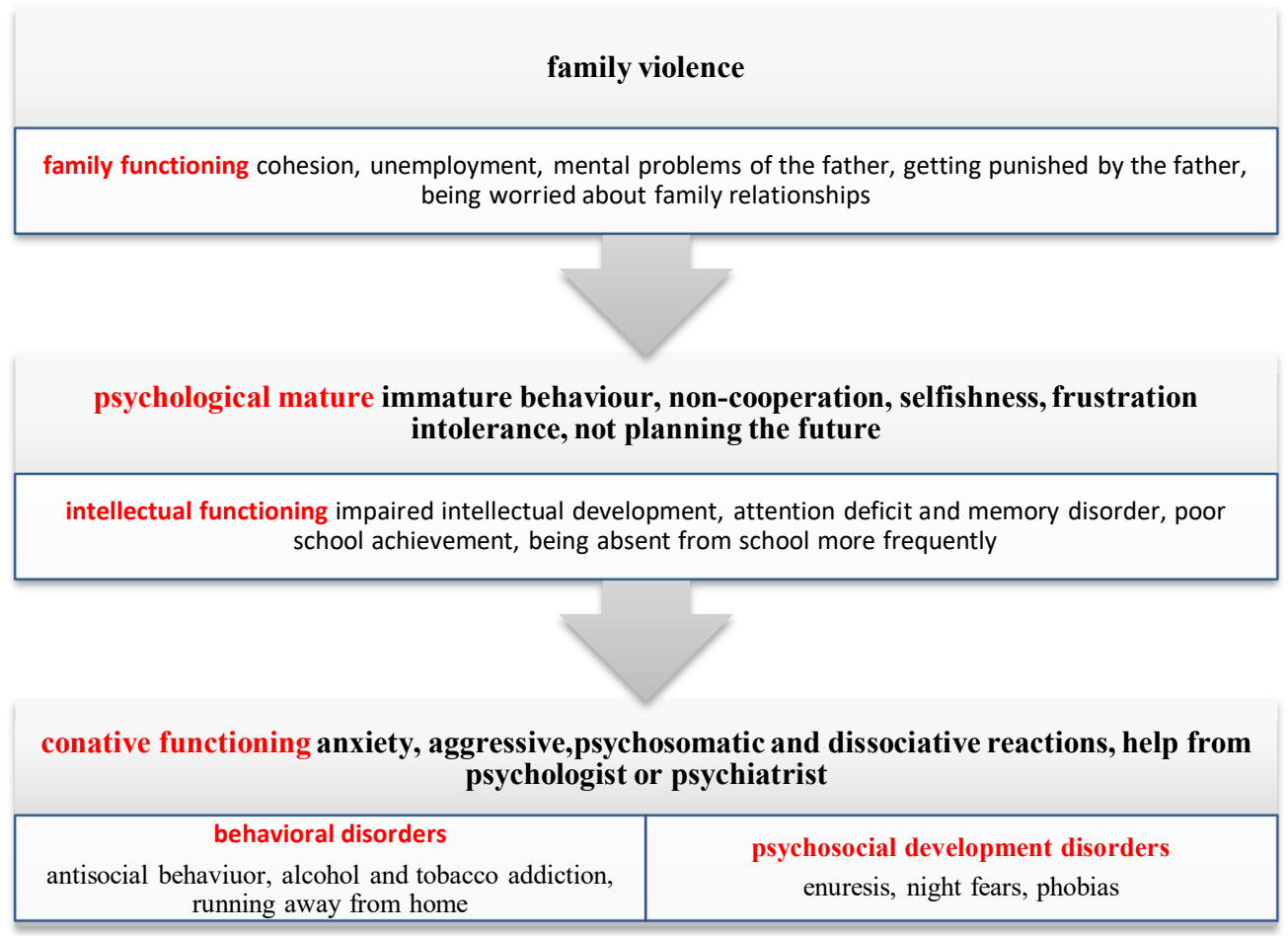

Significant negative correlations were obtained between family violence and psychosocial development of adolescents.

The study showed that the adolescents growing up in violent families had significant development disorders in: night fears $(\beta=.-722,82.4 \%$ vs. $5.0 \%)$, phobias $(\beta=-.586,64.7 \%$ vs. $5.45 \%)$ and enuresis $(\beta=-.323,11.76 \%$ vs. $.0 \%)$.

Obtained negative correlations pointed out that family violence significantly increased adolescent behavioral disorders: running away from home $(\beta=-.569,35.3 \%$ vs. $.0 \%)$, breaking rules and getting punished at school $(\beta=-.569$, $44.1 \%$ vs. $.8 \%)$, conflicts with peers $(\beta=-.460,29.4 \%$ vs. $.8 \%)$, alcohol addiction $(\beta=-.428,79.4 \%$ vs. $37.5 \%)$.

Impaired emotional, intellectual and social development of adolescents from violence families were accompanied by slower development of psychological, latent maturity ( $\beta=.618, M=17.65 \pm 2.215$, category 4 - predominantly mature behavior, vs. $\mathrm{M}=12.00 \pm 3.339$, category 2 - predominantly immature behavior) and maturity dimensions: cooperation with other people $(\beta=.523, M=160.47 \pm 16.279$, category 4 - high, vs. $M=127.588 \pm 25.958$, category $2 / 3$ borderline moderate/developed), orientation towards the future ( $\beta=669, M=4.89 \pm 0.466$, category - pronounced need for accomplishing one's values in life, vs. $\mathrm{M}=3.088 \pm .1 .42$, category - perceiving obstacles in planning the future and carrying out the potential), frustration tolerance $(\beta=-.416$, negative correlation pointed out to the fact that family violence lowered the readiness to deal with a failure; $M=99.88 \pm$ 10.225 , category 4 - high, vs. $M=83.382 \pm 16.720$, category 3 - developed), trust in people $(\beta=-.368$, negative correlation showed that family violence lowered trust in people, $M=121.46 \pm 12.368$, category 3 - developed, vs. $M=106.205$ \pm 13.143 , category 2 - moderate), lowered selflessness $(\beta=.348, M=71.21 \pm 9.102$, category 3 - developed, vs. $\mathrm{M}=59.941 \pm 15.233$, category 2 - moderate).

\section{DISCUSSION}

Family violence significantly damaged functionality and structure of all the subsystems as well as their mutual association (27). Altered behavior consequently threatened to destroy the wholeness of a dysfunctional family, triggering chain changes in the functioning of other family subsystems and their mutual relationships in the form of intemperance, unpredictability, emotional cut-offs or distance, the feeling of failure to fulfill one's one role as well as the feeling of other people's failure to fulfill their roles (21).

Family violence exhibited pronounced unemployment and bad financial conditions. Family's failing to fulfill its financial role as regards providing necessary prerequisites for satisfying basic physiological and psychological needs was associated with failing to satisfy the motive for material and psychological security of the family's subsystems and bad emotional relationships within it (28). Disorders of emotional 
relationships within dysfunctional families were reinforced by a significantly higher rate of children getting punished by parents in violent families. A large number of adolescents from violent families showed a markedly pronounced fear of the father (29). The quality of emotional relationships within violent families was damaged the most between the husband and wife i.e. within the marital dyad. The relationships within the marital dyad in violent families were characterized by the presence of various forms of violence and communication problems (30).

Structural and dynamic changes of violent families significantly affected the level of the adolescents being worried about their family relationships (31). Growing up of adolescents in violent families was significantly associated with difficulties in psychosocial functioning, because of which they showed an increased need for getting professional help from the psychologist and psychiatric with the aim of restoring homeostasis in their own system or attaining self-regulation and normal functionality of personality (32).

Violent families were significantly characterized by the presence of family pathology which disrupted the accomplishment of basic dimensions of cohesion and communication, lowering closeness, warmth and sense of unity (33).

Adolescent exposure to family violence made their intellectual development more difficult. Attention deficit disorder, adolescents' memory difficulties were associated with a significantly lower school achievement. Exposure to chronic negative family stress and various forms of violence affected increased excused and unexcused leave from school. A high rate of unexcused leave from school on the part of adolescents from dysfunctional families provided the basis for mandating educational-disciplinary measures. Obtained data on the significantly lower school achievement (11) of adolescents growing up in violent families represented the consequence of absence of cognitive stimuli provided in the family because of the following: fathers uninterested in carrying out their role as regards the in children's education, poor material conditions, pronounced psychopathology of the parents, low cohesion and impaired communication. Family violence brought about poor school achievement, due to overall decreased social and intellectual stimulation and lack of media influence: TV, the Internet, music, low physical activity, substance use disorder and emotional problems of adolescents (34). Certain studies of internalized problems of adolescents from violent families associated anxiety and depression with learning problems due to psychobiological mechanisms. High alert of the nervous system (arousal) and years' long exposure to stress led to decreased agility, learning problems and externalized symptoms (35).

Conative functioning of adolescents growing up in violent families was significantly different in hierarchically lower and higher dimensions (26). Adolescents from violent families showed significantly bigger depressive reactions $(13,36,37)$, anxiety, aggressive, psychosomatic reactions and a higher risk for developing psychosomatic diseases (38).
Disorders in the functioning of the Regulator of Defense Reactions led to the anxiety symptom, which provided the basis for pathological reactions such as: phobias, obsession, compulsiveness, sensory and emotional hypersensitivity, posttraumatic stress disorder $(39,40,41)$. Characteristics of dysfunctional communication in violent families include lower levels of verbal expression and emotional reactions, lower tolerance to criticism and its intimate interpretation, which increased the anxiety and a number of reasons for violence (42). Reactions of the Attack Regulator or aggressive reactions were significantly more pronounced with the adolescents from violent families. Under unfavorable circumstances, increased aggressive reactions in this group might bring about a lot of externalized symptoms such as: impulsiveness, destructiveness, behavioral disorders, delinquency (43). Aggressive reactions of adolescents from violent families were associated with the mental health of the mother, lack of maternal love and warmth, physical punishing of the children (44).

Dysfunction of lower conative regulators on the part of the adolescents from violent families, psychosomatic, anxiety and aggressive reactions, was associated with significant disorders in the functioning of the supervising System for Regulating Function Coordination (45). Pathological values of the System for Regulating Function Coordination brought about the disorganization of cognitive and conative processes, motoric function disorders, schizophrenic, paranoid, manic, more severe forms of sensory and motoric conversion, some form of inhibitory conversion and fixated phobia, obsession and compulsion (46).

Disorders of hierarchically lower conative dimensions of adolescents from violent families brought about significant differences in the functioning of the highest Regulation Function Integration System. Pathological functioning of the Regulation Function Integration System was associated with social dis-adaptation, lower level of social maturity and externalized symptoms. Exposure to family dysfunctionality caused by family violence along with parental psychopathology and low self-regulation on the part of the adolescents brought about antisocial behavior, alcohol addiction, aggression, hostile reactions and trans generational violence transfer $(9,19,43,47)$.

Psychosocial development of adolescents from violent families was significantly associated with a number of disorders (48). Family violence within the family was associated the most with the occurrence of night dears, phobias and enuresis. Psychosocial development disorders of adolescents from violent families were the consequence of long-term exposure to negative family stress, open conflicts and traumatic experiences. Traumatic symptoms, flash episodes, impaired communication and lack of closeness with parents were associated with the occurrence of psychosocial development disorders (49).

Growing up of adolescents in violent families was associated with a larger number of behavioral disorders. 
Adolescents from violent families showed a significantly higher rate of abandoning their families and attempting suicide; they broke more school and social rules, because of which they got punished more often (50). Disrupted parentchildren relationships, low cohesion, emotional loneliness, insecurity in social skills caused overall inadequacy, running away from problems and reality by abandoning their own home or attempting suicide. Poor material wellbeing and tendency to exhibit uncontrollability in communication enhanced suicide rate of adolescents from violence families (51).

The most significant data on the effect of family violence on psychological functioning of adolescents were obtained in the domain of psychological maturity development. Adolescents from a violent family environment scored two category lower psychological maturity when compared with adolescents from functional families. Psychological functioning of adolescents from violent families reached the level of predominantly immature behavior, as opposed to adolescents from functional families who, in their functioning, reached predominantly mature behavior. Family violence hindered integrative personality abilities in terms of achieving one's personal identity, i.e. family functioning disorders resulted in having difficulties when it came to achieving homeostasis on the part of the adolescent, as a subsystem.

Family violence was associated with the formation of immature personality, the kind of immaturity that Hrnjica (24) called "underdeveloped personality immaturity". The feeling of not being loved, absence of closeness with parents caused insecurity, emotional instability, identification and integration process disorders. This type of non-maturity had its existing forms in antisocial behavior (alcoholism, delinquency, loitering, psychopathic) and neurotic behavior (escape from reality).

Adolescents from violent families had significantly lower dimensions of maturity; frustration tolerance, orientation towards the future (52). Diminished cooperation with other people on the part of adolescents from violent families was the result of low personality integrity. Lower level of association among values, characteristics, self-image and motives diminished control over acquired differentiation and the number of contact with other people (24). Anger and negative emotions of adolescents from violent families caused distrust and poor cooperation with other people (53). Impaired emotional, conative and intellectual development of the adolescents from violent families, together with learning problems and lower school achievement and psychological maturity caused uninterestedness and fear of the future (54).

Family psychopathology and family conflicts caused a high risk of alcohol problems on the part of adolescents from violent families. Family violence disrupted the relationship among the siblings, enhanced aggression and led to compulsory alcohol abuse (52).
Growing up in violent families whose functionality was both structurally and dynamically impaired, significantly disturbed psychological functioning of an adolescent, as a family subsystem. Difficulties in intellectual, conative and behavioral functioning brought about the inability of achieving personal integrity and attaining psychological maturity. Family homeostasis disorders were associated with difficulties in achieving personal homeostasis on the part of the adolescent in the process of morphogenesis and they were accompanied by the risk of occurrence of internalized and externalized symptoms.

\section{Limitations}

The results of the study were based on the self-evaluation values of family and personal dimensions. Therefore, the conclusions were associated with the respondents' ability to describe their own as well as their family dimensions.

Although the study encompassed a large number of family and psychological variables, some variables were not included (psychological or psychiatric evaluation of parents from violent families, duration and severity of exposure to family violence, duration of medical attention after reporting intimate partner violence), which might be the subject matter of some other study.

\section{ACKNOWLEDGMENTS}

The author is sincerely grateful to all people in The Centre for Social Work in Vranje and Secondary School Gimnazija in Vranje who contribute to this study.

\section{CONCLUSIONS}

The study pointed out that growing up in a dysfunctional family system, causedby violence, multiply damaged in terms of basic dimensions, cohesion and communication among subsystems was associated with cognitive, conative, social and emotional-behavioral development and that it structured specific characteristics and significantly predicted psychopathological symptomatology of adolescents from such families.

Inter-family violence exposure during adolescent development predicted the following: pronounced level of being worried about family relationships, night fears, enuresis, need for professional help, lower level of cooperation with other people, lowered orientation towards the future and lower level of latent maturity acquired, pronounced psychosomatic, anxiety, aggressive and dissociative reactions, more frequent absence from school, pronounced attention deficit and memory disorders, running away from home, breaking rules and getting punished at school, conflicts with peers, lower frustration tolerance, distrust of people, selfishness, social mal adaptation, impaired intellectual development and alcohol addiction. The mediators between the functioning of 
a violent family system and adolescent personality psychosocial development were: mental problems of the father, disrupted relationships within the marital dyad, low cohesion and unemployment and psychopathology of the father.

Scientific significance of this work was shedding light on the mechanisms of specific adaptation on the part of adolescents from violent families to growing up in a dysfunctional family system, i.e. inter-family violence families. The possibility of developing psychopathological symptoms pointed out to the need of undertaking certain preventive, mental-hygienic measures in working with adolescents growing up in and exposed to family violence.

\section{REFERENCES}

1. De Fife JA, Drill R, Nakash O, Westen D.Agreement between clinician and patient ratings of adaptive functioning and developmental history. American Journal of Psychiatry 2010; 23: 45-78.

2. Elmquist JA, Shorey RC, Labrecque L, Ninnemann, A, Zapor H, Febres J, et al. The Relationship Between Family-of-Origin Violence, Hostility, and Intimate Partner Violence in Men Arrested for Domestic Violence. Violence 2015; 22 (10): 1243-58. doi: $10.1177 / 1077801215621177$.

3. Thrap AT, Schumacher JA, Samper RE, McLeish AC, Coffey SF. Relative importance of emotion dysregulation, hostility, and impulsiveness in predicting intimate partner violence perpetrated by men in alcohol treatment. Psychology of Women Quarterly 2013; (37): 5160 .

4. Garcia Moreno C et al. WHO multi-country study on women's health and domestic violence against women: initial results on prevalence, health outcomes and women's responses. Geneva: World Health Organization; 2005.

5. Heise L, Garcia Moreno C. Violence by intimate partners, in Krug EG et al., eds. World report on violence and health. Geneva: World Health Organization; 2002: 87-121.

6. Holmes MR. Aggressive behavior of children exposed to intimate partner violence: an examination of maternal mental health, maternal warmth and child maltreatment. Child Abuse Negl 2013; 37(8): 520-30. doi: 10.1016/j.chiabu. 2012.

7. Lecic-Tosevski D, Draganic-Gajic S, Pejovic-Milovancevic M, Popovic-Deusic S, Christodoulou N, Botbol M. Child is father of the man: child abuse and development of future psychopathology. Psychiatriki 2014; 25(3): 185-91.

8. Feinberg EM, Solmeyer AR, McHale SM. The Third Rail of Family Systems: Sibling Relationships, Mental and Behavioral Health, and Preventive Intervention in Childhood and Adolescence. Clin Child Fam Psychol Rev 2012; 15(1): 43-57.doi:10.1007/s10567-011-01045 .
9. Visser MM, Telman MD, de Schipper JC, Lamers-Winkelman F, Schuengel C, Finkenauer C. The effects of parental components in a trauma-focused cognitive behavioral based therapy for children exposed to inter parental violence: study protocol for a randomized controlled trial. BMC Psychiatry 2015; 23:15-131. doi: 10.1186/s12888-015-0533-7.

10. Seijo D, Fariña F, Corras T, Novo M, Arce R. Estimating the Epidemiology and Quantifying the Damages of Parental Separation in Children and Adolescents. Front Psychol2016 25; 7: 1611. eCollection 2016.

11. Carpenter GL, Stacks AM. Developmental effects of exposure to intimate partner violence in early childhood: A review of literature, Children and Youth Services Review 2009; 31: 831-39.

12. Beckmann L, Bergmann MC, Fischer F, Mößle T. Risk and Protective Factors of Child-to-Parent Violence: A Comparison Between Physical and Verbal Aggression. J Interpers Violence 2017: 886260517746129. doi: $10.1177 / 0886260517746129$.

13. Miranda JK, de la Osa N, Granero R, Ezpeleta L. Maternal experiences of childhood abuse and intimate partner violence: Psychopathology and functional impairment in clinical children and adolescents. Child Abuse Negl 2011; 35(9): 700-11. doi: 10.1016/j.chiabu.2011.05.008.

14. Ozer EJ, Lavi I, Douglas L, Wolf JP. Protective Factors for Youth Exposed to Violence in Their Communities: A Review of Family, School, and Community Moderators. J Clin Child Adolesc Psychol 2015; 26: 1-26. PMID: 26114611.

15. Izaguirre A, Calvete E. Exposure to Family Violence and Internalizing and Externalizing Problems Among Spanish Adolescents. Violence Vict 2018; 33(2): 368-382. doi: 10.1891/0886-6708.VV-D-1700016.

16. Butler JF. Family Psychotherapy: The First Evolutionary Stage during the NIMH Family Study Project. Family Systems Journal 2013; 10(1): 29-42.

17. Enlow MB, Blood E, Egeland B. Sociodemographic risk, developmental competence, and PTSD symptoms in young children exposed to interpersonal trauma in early life. J Trauma Stress 2013; 26(6): 686-94.

18. Alisic E, Krishna RN, Groot A, Frederick JW. Children's Mental Health and Well-Being After Parental Intimate Partner Homicide: A Systematic Review. Clin Child Fam Psychol Rev 2015; 18(4): 328-45.doi: 10.1007/s10567-015-0193-7.

19. Espelage DL, Holt MK. Suicidal ideation and school bullying experiences after controlling for depression and delinquency. J Adolesc Health. 2013; 53 (1 Suppl): S2731. doi: 10.1016/j.jadohealth.2012.09.017.

20. Ehrensaft MK, Cohen P. Contribution of family violence to the intergenerational transmission of externalizing behavior. Prev Sci 2012; 13(4): 370-83.doi: 10. 1007/s11121-011-0223-8.

21. Campbell J, Pinkerton J, edit. Systemic Family Therapy for Families who have Experienced Trauma: A Randomised Controlled Trial. Br J Soc Work 2011; 41(4/1): 502519. 
22. Conners K, Sitarenios G, Parker JDA, Epstein J. The Revised Conners, Parent Rating Scale (CPRS-R): Factor Structure, Reliability, and criterion Validity. Journal of Abnormal Child Psychology 1998; 26(4): 257-668.

23. Olson D. Outcome Study of Alcoholic Families Polish FACES. J FamTher 2014.

24. Hrnjica S. Zrelost ličnosti. Beograd: Zavod za izdavanje udžbenika i nastavna sredstva; 1992; 8: 145-92.

25. Potočnik-Bele Ž, Hruševar B, Tušak M. Test rezonovanja likova -TRL. Ljubljana: Zavod SR Slovenije za produktivnost dela; 1984.

26. Momirović K, Wolf B, Đžamonja Z. KON-6 Kibernetički model ličnosti. Beograd: SDPS - Centar za prmenjenu psihologiju; 2002-2015.

27. Tolou-Shams M, Brogan L, Esposito-Smythers C, Healy MG, Lowery A, Craker L, et al. The role of family functioning in parenting practices of court-involved youth. J Adolesc 2018; 63: 165-174. doi: 10.1016/j.adolescence.2017.12.016.

28. Murphy-Edwards L, van Heugten K. Domestic Property Violence: A Distinct and Damaging Form of Parent Abuse. J Interpers Violence 2015; 17 . doi: 10.1177/0886260515613341

29. Macdonald GS. Domestic Violence and Private Family Court Proceedings: Promoting Child Welfare or Promoting Contact? Violence Against Women 2016; 22(7): 832-52. doi: 10.1177/1077801215612600.

30. Stover CS, Kiselica A. An initial examination of the association of reflective functioning to parenting of fathers. Infant Ment Health J 2014; 35(5): 452-61. doi: 10.1002/imhj.21459.

31. Ottaviani C, Lonigro A, Cioffi B, Manzi D, Laghi F, Baiocco R. Family functioning and parents' dispositions moderate the affective, attentional and physiological consequences of rumination in children. Biol Psychol 2017; 127: 220-228. doi: 10.1016/j.biopsycho.2017.06.003.

32. Rounsaville D, O'Farrell TJ, Andreas JB, Murphy CM, Murphy MM. Children's exposure to parental conflict after father's treatment for alcoholism. Addict Behav 2014; 39(7): 1168-71. doi: 10.1016/j.addbeh.2014.03.017.

33. Pye RE, Simpson LK. Family Functioning Differences Across the Deployment Cycle in British Army Families: The Perceptions of Wives and Children. Mil Med 2017; 182(9): e1856-e1863. doi: 10.7205/MILMED-D-1600317.

34. Capaldi DM, Pears KC, Kerr DC, Owen LD, Kim HK. Growth in externalizing and internalizing problems in childhood: a prospective study of psychopathology across three generations. Child Dev 2012; 83(6): 194559.doi: 10.1111/j.1467-8624.2012.01821.x.

35. Vandewater EA, Park SE, Carey FR, Wilkinson AV. Intergenerational transfer of smoking across three generations and forty-five years. Nicotine Tob Res 2014; 16(1): 11-7. doi: 10.1093/ntr/ntt112.

36. Moylan CA, Herrenkohl TI, Sousa S, Tajima EA, Herrenkohl RC, Russo JM. The Effects of Child Abuse and Exposure to Domestic Violence on Adolescent
Internalizing and Externalizing Behavior Problems. J Fam Violence 2010; 25(1): 53-63.

37. Guček NK, Selič P. Depression in Intimate Partner Violence Victims in Slovenia: A Crippling Pattern of Factors Identified in Family Practice Attendees. nt J Environ Res Public Health 2018; 15(2). pii: E210. doi: 10.3390/ ijerph 15020210.

38. Simonović Grujić Lj. The association between conative functioning of adolescents exposed to intimate partner violence and family dimensions of cohesion and adaptability. Vojnosanitetski pregled 2018: 9 doi.org/ 10.2298/ VSP170514009S189

39. Zimmerman GM, Posick C. Risk Factors for and Behavioral Consequences of Direct Versus Indirect Exposure to Violence. Am J Public Health 2016; 106(1): 178-88. doi: 10.2105/AJPH.2015.302920.

40. Dorrington S, Zavos H, Ball H, McGuffin P, Sumathipala A, Siribaddana et al. Family functioning, trauma exposure and PTSD: A cross sectional study.J Affect Disord. 2018; 245:645-652. doi: 10.1016/j.jad.2018.11.056.

41. Kugler BB, Bloom M, Kaercher LB, Truax TV, Storch EA. Somatic symptoms in traumatized children and adolescents. Child Psychiatry Hum Dev 2012; 43(5): 66173. doi: 10.1007/s10578-012-0289-y.

42. Bunston W, Franich-Ray C, Tatlow S. A Diagnosis of Denial: How Mental Health Classification Systems Have Struggled to Recognise Family Violence as a Serious Risk Factor in the Development of Mental Health Issues for Infants, Children, Adolescents and Adults. Brain Sci 2017; 7(10). pii: E133. doi: 10.3390/brainsci7100133.

43. Hardaway CR, McLoyd VC, Wood D. Exposure to violence and socioemotional adjustment in low-income youth: an examination of protective factors. Am J Community Psychol 2012; 49(1-2): 112-26.

44. Källström Å, Hellfeldt K, Howell KH, Miller-Graff LE, Graham-Bermann SA. Young Adults Victimized as Children or Adolescents: Relationships Between Perpetrator Patterns, Poly-Victimization, and Mental Health Problems. J Interpers Violence 2017; 886260517701452. doi: 10.1177/0886260517701452.

45. Peltonen K, Kangaslampi S, Saranpää J, Qouta S, Punamäki RL. Peritraumatic dissociation predicts posttraumatic stress disorder symptoms via dysfunctional trauma-related memory among war-affected children. Peritraumatic dissociation predicts posttraumatic stress disorder symptoms via dysfunctional trauma-related memory among war-affected children. Eur J Psychotraumatol 2017; 10; 8(sup3): 1375828. doi: 10.1080/20008198.2017.1375828.

46. Martinez W, Polo AJ, Zelic KJ. Symptom variation on the trauma symptom checklist for children: a withinscale meta-analytic review. J Trauma Stress 2014; 27(6): 655-63. doi: 10.1002/jts.21967.

47. Guenther KD, Van Dyk TR, Kidwell KM, Nelson TD. The Moderating Role of Dysfunctional Parent-Child Relationships on the Association between Outward Anger Expression and Physical Health in Youth from Low- 
Income Families. Pediatr Health Care 2016; 30(4): 36673. doi: 10.1016/j.pedhc.2015.09.007.

48. Dubas JS, Baams L, Doornwaard SM, van Aken MAG. Dark personality traits and impulsivity among adolescents: Differential links to problem behaviors and family relations. J Abnorm Psychol 2017; 126(7): 877-889. doi: $10.1037 /$ abn 0000290. 208

49. Giupponi G, Giordano G, Maniscalco I, Erbuto D, Berardelli I, Conca A, et al. Suicide risk in attentiondeficit/hyperactivity disorder. Psychiatr Danub 2018; 30(1): 2-10. doi: 10.24869/psyd.2018.2.

50. Turanovic JJ, Pratt TC. Longitudinal effects of violent victimization during adolescence on adverse outcomes in adulthood: a focus on prosocial attachments. J Pediatr 2015; 166(4): 1062-9.e1. doi: 10.1016/j.jpeds. 2014. 12.059 .

51. Liu YY, Wang XT, Qiu HM, Xu AQ, Jia CX. Functional and dysfunctional impulsivity and attempted suicide in rural China: A paired case-control study.
Psychiatry Res 2017; 253: 22-27. doi: 10.1016/j.psychres.2017.03.025.

52. Conger RD, Martin MJ, Masarik AS, Widaman KF, Donnellan MB. Social and economic antecedents and consequences of adolescent aggressive personality: Predictions from the interactionist model. evPsychopathol 2015; 27(4 Pt 1):1111-27. doi: $10.1017 /$ S0954579415000711.

53. Birkley EL, Eckhardt CI. Anger, hostility, internalizing negative emotions, and intimate partner violence perpetration: A meta-analytic review. Clin Psychol Rev 2015; 37: 40-56. doi: 10.1016/j.cpr.2015.01.002.

54. Baptista J, Belsky J, Marques S, Silva JR, Oliveira $\mathrm{P}$, Mesquita A, et al. The interactive effect of maltreatment in the family and unstable institutional caregiving in predicting behavior problems in toddlers. Child Abuse Negl 2014; 38(12): 2072-9. doi: 10.1016/j.chiabu.2014.10.015. 